author, title, sponsoring agency, size (in terms of printing sheets), size of edition and scheduled time of publication. Except where otherwise stated, all books are published by the Academy of Sciences. Synopses can be supplied on request at a cost of $7 s, 6 d$. each, including postage. Some 1,255 titles are listed.

The Directorate for Scientific Affairs of the Organization for Economic Co-operation and Development has issued an index to issues 1 to 12 of the bulletin Russian Technical Literature, covering the period February 1960 October 1963 (Pp. 58 . Paris: The Directorate for Scientific Affairs of the Organization for Economic Co-operation and Development, 1963). Entries are arranged alphabetically under author and subject, and entries relating to original contributions are differentiated. Titles of translated books are entered in the language into which they have been translated.

\section{Bulletin of the International Computation Centre}

THE April issue of the Bulletin of the International Computation Centre in Rome contains three interesting papers concorned with the use of integrated computer systems in research and education-the latter both from the point of view of administration and of instruction. A paper by Tadatoshi Sakai, who is head of the Data Processing Section of the Bureau of Statistics, attached to the Prime Minister's Office in Japan, is of particular interest in showing the way in which the Japanese have adapted some notions on automatic programming to their IBM 705 data-processing system. In addition to the scientific papers there are a number of book reviews and notes of forthcoming conferences in the fiold of computation.

\section{A Television Station in the Desert}

According to a recent article in The Lamp (45, No. 4; Winter 1963), quarterly publication of the Standard Oil Company (New Jersey), Baghdad was the first television transmitting station to be established in the Middle East. In 1957 the Arabian American Oil Company ('Aramco'), an affiliate of Standard Oil, sponsored the setting up of the second station at Dhahran in the desert region of eastern Saudi Arabia. This was later followed by the establishment of television stations in Beirut, Cairo, Damascus, Kuwait, Abadan and Tehran. 'Channel 2 Dhahran', as it is called, can claim certain distinctions. In the first place 'Aramco Television' is probably the only social and cultural facility of its kind operated by an industrial firm. Secondly, it is the only station broadcasting entirely in Arabic. When it first came on the air the intention of the Company was to provide entertainment, information and education for 11,000 local employees and their families. "This audience is vastly outnumbered to-day by an estimated 100,000 or more viewers who can be reached by the Dhahran transmitter and a newly opened relay station sixty miles away. The number of receivers in the region has grown to about 16,000 , and selling and servicing sets has provided new jobs and a brisk business for Saudi Arab merchants." The Dhahran station operates from a building situated not far from the original discovery oil-well in this desert region, the antenna being sited on the top of an old drilling rig. The station includes studio and control room for live programmes, film-processing laboratory, offices and a 'dubbing' booth; this last facility is of great importance because by means of 'dubbed-in' dialogue rendered by people who speak fluent Arabic, the charactors and themes of many well-known American television films and productions are thus mado available to these desert audiences. As regards programme policy, Arameo telovision devotes about one-third of its air-time ( 32 hours per week) to information and education; local events are covered by the station's own camera and sound-truck; Arabic-speaking doctors discuss hygiene, and pre- and post-natal care, among other subjects concerned with the health of the community. Although provision is made for non-Arabic viewers to enjoy imported films, by tuning their sets to a wave-length broadcasting the original soundtrack, one of the perhaps unexpected results of this enterprise has been to encourage many to learn Arabic.

\section{New Barley Varieties in Europe}

The European Brewery Convention Report of the Barley Committee: Trials, 1962 (Pp. 138. 1964), presents the results of comparative trials of new barley varieties in twelve European countries both from the agricultural and malting points of view. From the first point of view, the trials consisted of $(a)$ comparisons of the variety 'Kenia', which was regarded as the standard, with three obligatory varieties, and $(b)$ local trials of some thirty additional varieties. Perhaps the major importance of these results in scientific literature is not the numerical values and assessment of specific qualities; rather is it to emphasize the complex organization required to give an overall picture of the acceptability of a new barley variety and perhaps of any agricultural crop when account has to be taken of climatic differences from country to country, climatic variations from year to year and differences in, for example, agricultural methods and susceptibility to disease in varying localities. Nevertheless, the summarized results and the country-by-country reports contain a wealth of tabulated information of a kind which would be very difficult to locate elsewhere. In addition, the Report includes summaries of papers presented at a joint mecting at which wider topies such as quality in malting barley, the development of barley breeding programmes and specific problems such as premature sprouting were considered. Radical new information is necessarily limited, but it will probably be helpful in similar fields to see how appreciation has grown of the value of regional agricultural experience and of objectively assessing a crop in terms which go far beyond the first consideration of yield per acre.

\section{British Palæozoic Fossils}

A GENUINE welcome is accorded the appearance of the Natural History Museum's publication British Palceozoic Fossils which completes the set of three very reasonably priced handbooks illustrating a representative selection of British fossils from the beginning of Cambrian times onwards (Pp. vi +208 (69 plates). London: British Museum (Natural History), 1964. 12s. 6d.). Though intended primarily as an aid to the interested layman, this series also provides a wealth of readily accessible information for the specialist, and one may cite, by way of examplo, the synonyms given, where necessary, for the species selected for illustration. In this third handbook, an introductory chapter outlines the geological history of the British Isles during the Palæozoic Era, while subsequent sections include stratigraphical tables for each of the six systems involved, the geological distribution of the species illustrated, and brief notes on the intricacies of species nomenclature. The greater part of the book (pp. 54-191), however, is devoted to annotated illustrations of the 443 species selocted to represent the Palæozoic. Having in mind the problems which must have confronted the authors, one is reluctant to criticize, but it is felt that certain improvements could have been implemented and at no extra cost. Thus, the illustrations are frequently too heavily shaded, giving insufficient contrast and consequent loss of detail, and it is unfortunate that less than 50 per cent of the species depicted are on display in the Museum. But such drawbacks are slight in comparison with the services rendered by this handbook.

\section{Canadian Anthropology}

A vaLUable collection of a pre-First World War field survoy with excavations appears in the Novembur 1963 issue of the National Museum of Canada Anthropology Papers (No. 4. The W. B. Nickerson Survey and Excava- 